\title{
Perkembangan Sosial Emosional Anak yang Mengalami Hambatan dalam Berinteraksi Sosial
}

\author{
Febriyanti Harun, Yenti Juniarti \\ Jurusan PG-PAUD Universitas Negeri Gorontalo \\ yenti.juniarti@gmail.com
}

\begin{tabular}{l} 
Info Artikel \\
\hline Sejarah Artikel: \\
Diterima (April) (2019) \\
Disetujui (Mei) (2019) \\
Dipublikasikan (Juli) (2019)
\end{tabular}

Keywords:

Sosial Emosional; Interaksi Sosial; Anak Usia Dini

\begin{abstract}
Abstrak
Penelitian ini berlatarbelakang anak yang mengalami hambatan dalam berinteraksi sosial yang bertujuan untuk mengetahui perkembangan sosial emosional anak yang mengalami hambatan dalam berinteraksi sosial. Penelitian ini menggunakan pendekatan kualitatif. Subjek pada penelitian ini adalah salah satu anak disekolah Aisyiyah Bustanul Athfal 7 yang bernama CK usia 5 tahun yang merupakan anak yang memiliki hambatan dalam berinteraksi sosial. Teknik pengumpulan data dalam penelitian ini adalah wawancara, pengamatan observasi dan kuesioner. Hasil penelitian menunjukkan bahwa selama masa pertumbuhan dan perkembangan anak akan selalu membutuhkan pengenalan terhadap banyak hal yang baru salah satunya adalah pengenalan dunia luar dan berinteraksi dengan orang lain selain anggota keluarga anak perlu berinteraksi dengan orang baru tetapi dengan pegawasan orang tuanya. Hal inilah yang menyebabkan anak yang bernama CK sulit untuk berinteraksi dengan orang yang baru dia kenal sehingga perlu adanya stimulasi seperti membiarkan anak ber eksplorasi terhadap segala hal yang ingin di ketahuinya.
\end{abstract}

\begin{abstract}
This research is background of children who experience obstacles in social interaction that aims to determine the emotional social development of children whp experience obstacles in social interaction. This research uses a qualitative approach. The subject in this study was one of the children at Aisyiyah Bustanul Athfal 7 school named CK 5 years old who is a child who has barriers to social interaction. Data collection techniques in this study were interviews, observation and questionnaires. The result showed that during a child's growth and development will always require the introduction of many new things, one of which is the introduction of the outside world and interacting with other people besides family members, childres need to interact with new people but with the supervision of their parents. This is what makes a child named CK difficult to interact with new people he knows so these needs to be stimulation such as letting children explore everythinh they want to know.
\end{abstract}




\section{Pendahuluan}

Menurut Undang-undang Republik Indonesia Nomor 20 Tahun 2003 tentang Sistem Pendidikan Nasional pada Pasal 1 ayat 14 menyatakan bahwa pendidikan anak usia dini adalah suatu upaya pembinaan yang ditujukan kepada anak sejak lahir sampai dengan usai enam tahun yang dilakukan melalui pemberian rangsangan pendidikan untuk membantu pertumbuhan dan perkembangan jasmani dan rohani agar anak memiliki kesiapan dalam memasuki pendidikan lebih lanjut.

Anak usia dini merupakan individu yang memiliki rentan usia 0-8 tahun. Anak usia dini sendiri merupaka sosok individu yang memiliki pola pertumbuhan dan perkembangan dalam aspek fisik, kognitif, sosial, emosional, kreatifitas, bahasa dan komunikasi yang khusus sesuai dengan tahapan yang sedang di lalui oleh anak tersebut. Masa emas inilah yang menentukan pola dan pondasi perkembangan masa berikutnya.

Perkembangan sosial emosional merupakan dua aspek yang berlainan, namun dalam kenyataannya satu sama lain saling mempengaruhi. Perkembangan sosial sangat erat hubungannya dengan perkembangan emosional, walaupun masing-masing ada ke khususannya. Perkembangan social emosional pada anak usia dini mengalami kemajuan yang sangat pesat.

Makna sosial dipahami sebagai upaya pengenalan (sosialisasi) anak terhadap orang lain yang ada diluar dirinya dan lingkungannya,serta pengaruh timbal balik dari berbagai segi kehidupan bersama yang mengadakan hubungan satu dengan lainnya, baik dalam bentuk peorangan maupun kelompok. Sedangkan makna emosi menurut Sukmadinata (2003) yaitu sebagai perpaduan dari beberapa perasaan yang mempunyai intensitas yang relative tinggi dan menimbulkan suatu gejolak suasana batin. Seperti halnya perasaan, emosi juga membentuk suatu kontinum, bergerak dari emosi positif hingga emosi negatif.

Setiap individu dari berbagai budaya menunjukkan ekspresi emosi seperti bahagia atau senang, marah, berduka, takut, tertawa karena lucu, dan lain-lain. Seperti juga dengan anak-anak yang lebih tua dan orang dewasa, emosi anak usia dini adalah bukti dalam menunjukkan ekspresi, bahasa tubuh, postur tubuh, bahasa tubuh yang lain, suara/vocal, bahasa, gaya komunikasi, dan perilaku yang ditimbulkan karena bermain dengan alat-alat mainan dan alat-alat pembelajaran. 
Perkembangan sosial berada dengan kemampuan sosial, kemampuan social merupakan kecakapan seorang anak untuk merespon dan mengikat perasaan dengan perasaan positif, dan memiliki kemampuan yang tinggi untuk menarik perhatian mereka. Didalam kemampuan sosial anak dituntut untuk memiliki kemampuan yang sesuai dengan tuntutan sosial dimana ia berada. Anak yang dapat berosialisasi dengan baik sesuai tahap perkembangan dan usianya cenderung menjadi anak yang mudah bergaul.

Interaksi sosial adalah hubungan sosial yang dinamis, berupa hubungan antara individu yang satu dengan yang lainnya, antara kelompok satu dengan kelompok lainnya, maupun antara kelompok dengan individu. Menurut Ahmadi (2009) interaksi sosial adalah suatu hubungan antara individu dengan individu ataupun individu dengan kelompok, dimana individu tersebut saling mengubah, saling mempengaruhi satu sama lain dari individu yang lainlah individu tersebut dapat berubah, belajar dan sebaiknya. Salah satu keterampilan yang harus dimiliki anak adalah kemampuan interkasi sosial. Jika interaksi sosial sejak anak usia dini sudah baik tentunya tahap interaksi berikutnya akan lebih baik juga.

Menurut Wiyani (2014) ketercapaian suatu kemampuan sosial pada setiap anak berbeda-beda. Untuk mengetahui apakah ketercapaian tersebut menggambarkan kemajuan atau tidak maka dibuatkan patokan atau standar yang perlu dicapai oleh anak usia 5-6 tahun yaitu: bersikap kooperatif, menunjukkan sikap toleran, mengekspresikan emosi dalam berbagai situasi (senang, gembira, antusias dan sebagainya), memahami peraturan dan disiplin, mengenal tata karma dan sopan santun sesuai dengan nilai sosial budaya setempat.

Menurut Nugraha (2014) lingkungan sosial individu pertama di bentuk dalam lingkungan keluarg. Lingkungan keluarga merupakan media pertama yang berpengaruh terhadap perilaku seseorang khususnya anak-anak, dimana dalam lingkungan keluarga anak diberikan berbagai pendidikan agar menjadi mandiri, untuk mengembangkan kemampuan mental, sosial, emosional maupun fisik yang ia miliki, sehingga dapat mengembangkan suatu kehidupan yang sehat dan juga produktif. Setelah itu, anak mulai memasuki fase sosialisasi yang sebenarnya yaitu di sekolah. 
Interaksi sosial tak akan mungkin terjadi apabila tidak memenuhi dua syarat (Hudaniah \& Dayakisni, 2006) yaitu kontak sosial, kontak sosial adalah hubungan satu pihak dengan pihak lain yang merupakan awal terjadinya interaksi sosial dan masingmasing pihak saling bereaksi meski tidak harus bersentuhan fisik. Kontak fisik dapat terjadi antara individu dengan individu, individu dengan kelompok, dan kelompok dengan kelompok. Komunikasi, komunikasi baik verbal maupun nonverbal merupakan saluran untuk menyampaikan perasaan ataupun ide/pikiran dan sekaligus sebagai media untuk dapat menafsirkan atau memahami pikiran atau perasaan orang lain.

Banyak hal yang mempengaruhi seorang anak mengalami kesulitan dalam bersosialisasi, contohnya kurang adanya komunikasi dan hubungan yang baik antara anak dan orang tua atau anggota keluarga lain di rumah sehingga menyebabkan anak sulit untuk berkomunikasi dan menjalani hubungan sosial yang baik, kemudian adanya fobia sosial misal berupa pengalaman bullying yang pernah dialami atau merasa di kucilkan dilingkungan sekitarnya, tipikal individu yang memiliki kepribadian tertutup, merasa rendah diri, kurang memiliki rasa percaya diri dan mengalami gangguan emosional.

\section{Metode Penelitian}

Penelitian ini menggunakan pendekatan kualitatif. Pendekatan kualitatif adalah sebuah metode yang menekankan pada aspek pemahaman lebih mendalam terhadap suatu masalah dari pada melihat sebuah permasalahan.

Waktu penelitian pada tanggal 9 Desembar 2019. Tempat penelitian di rumah anak yang mengalami hambatan dalam interaksi sosial yaitu di Jalan Brigjen Piola Isa, Kecamatan Kota Utara, Kota Gorontalo, Provinsi Gorontalo

Subjek pada penelitian ini adalah seorang anak mengalami masalah dalam berinteraksi sosial yang berumur 5 tahun. Anak yang akan di teliti yaitu anak yang berada di lingkungan peneliti. Sehingga peneliti dengan mudah mendapatkan informasi.

Peneliti melakukan penelitiannya dengan langsung mengunjungi rumah anak tersebut. Anak ini tinggal berseblahan rumah dengan peneliti. Dengan mewawancarai orang tua dan mencoba untuk berinteraksi dengan anaknya. 
Metode pengumpulan data dalam penelitian ini adalah wawancara, pengamatan observasi dan kuesioner. Dalam metode wawancara ini merupakan salah satu metode yang dapat dipercaya untuk mendapatkan data tentang individu yang dilakukan dengan pemberian pertanyaan-pertanyaan yang relevan secara tatap muka, peneliti melakukan wawancara kepada orang tua dari anak yang mengalami masalah dalam berinterkasi sosial.

Metode observasi adalah pengamatan atau pencatatan secara sistematik gejala yang tampak pada objek penelitian. Kuesioner yang dimaksud dalam penelitian ini adalah sejumlah pertanyaan tertulis yang digunakan untuk memperoleh informasi reponden dalam arti laporan tentang pribadinya atau hal-hal yang ia ketahui. Teknik analisis yang di gunakan dalam penelitian ini adalah reduksi data, penyajian data dan penarikan kesimpulan.

\section{Hasil Penelitian dan Diskusi}

Berdasarkan hasil penelitian ini di peroleh bahwa anak yang merupakan salah satu anak disekolah Aisyiyah Bustanul Athfal 7 yang bernama CK usia 5 tahun yang merupakan anak yang memiliki hambatan dalam berinteraksi sosial.

Dari observasi dan wawancara yang saya lakukan saya mendapatkan informasi bahwa ketika anak berinteraksi dengan orang yang sudah di kenalnya seperti temanteman yang ada dilingkungan sekolahnya dan lingkungan keluarganya ia terlihat begitu akrab dan aktif dalam berinteraksi tetapi saat bertemu dengan orang yang tidak di kenalnya dan orang itu berusaha untuk mengajaknya berinteraksi dia hanya diam dan tidak mau berbicara bahkan menjadi orang yang pemarah. Karena orang tuanya tidak membiasakan ia untuk berinteraksi dengan orang lain sehingganya ia hanya terbiasa dengan orang yang sudah ia kenal. Sebagai orang tua tentu harus mengetahui bahwa rasa percaya diri merupakan sebuah pondasi penting bagi kehidupan mental dan sosial seorang anak.

Pada saat CK masih bayi ibunya selalu membiasakan untuk menggendong bahkan pada saat ia menangis si ibu langsung lari untuk menggendongnya. Cara orang tua seperti ini akan berdampak kepada perkembangannya yang akan membuat anak menjadi manja sehingga ia selalu bergantung kepada orang tua, dan tidak akan menjadi anak yang mandiri. 
Namun kenyataannya, tidak semua anak bisa dengan mudah berinteraksi dengan orang yang baru dikenalnya. Sebagian tidak mau untuk keluar rumah, sebagian merasa malu jika berinteraksi dengan orang lain, sebagian yang lain menolak keras untuk bertemu dengan orang lain.

Hal itu disebabkan oleh beberapa faktor seperti sikap pemalu dan pendiam merupakan karakter bawaan sejak dia lahir, hal itu dapat terlihat dari seorang anak yang ramah, senang tersenyum ketika berinteraksi dengan orang yang baru dikenal. Sementara itu ada anak yang langsung menangis pada saat bertemu dengan orang yang baru dikenalnya.

Pola asuh yang keliru karena lingkungan sosial yang tidak nyaman bagi anak untuk melakukan interaksi. Tidak memberikan kesempatan untuk berinteraksi, salah satu penyebab anak pendiam dan pemalu ketika bertemu dengan orang juga karena tidak punya kawan sebaya sebagai teman bermain, anak tidak tahu bagaimana memperkenalkan dirinya atau berinteraksi dengan anak lain karena tidak pernah diajak bermain diluar.

Biasanya juga terjadi karena orang tua yang pemalu, jarang tersenyum,banyak menutup diri dan tidak pernah bergaul dengan orang lain karena merasa kehidupannya tidak cocok dengan orang lain.

Faktor yang dapat mempengaruhi perkembangan sosial anak yaitu hubungan antara orang tua, saudara. Hubungan anak dengan orang tua ataupun saudara akan terjalin rasa kasih saying, dimana anak akan lebih terbuka dalam melakukan interaksi karena terjalinnya hubungan yang baik yang di tunjang oleh komunikasi yang tepat.

Hal inilah yang menyebabkan anak yang bernama CK sulit untuk berinteraksi dengan orang yang baru dia kenal sehingga perlu adanya stimulasi seperti membiarkan anak ber eksplorasi terhadap segala hal yang ingin di ketahuinya namun tentu saja anak harus tetap berada dalam pengawasan orang tua ketika ia sedang melakukan aktifitas atau eksplorasi yang bisa membuatnya beresiko atau berbahaya baginya.

Masukkan anak kesekolah jika sudah pada waktunya, ketika anak sudah waktunya masuk sekolah sebaiknya jangan ditunda. Dengan demikian anak akan belajar untuk mengenal berbagai macam karakter orang dan belajar beradaptasi dengan 
lingkungan luar rumah. Anak bermain sambil mengasah kemampuan diri melalui bersosialisasi dengan teman sebaya.

Mengajak anak untuk melakukan kunjungan ke tetangga, sanak saudara atau teman-teman, atau tempat ayah dan ibunya bekerja, mengundang teman sebayanya untuk datang kerumah, mintalah kepada anak untuk menatap mata ketika berkomunikasi dengannya sehingga anak terlatih memiliki kontak mata dengan lawan bicara, karena pada saat berbicara dengannya pastikan memiliki kontak mata dengan anak yang penuh dengan kelembutan dan cinta.

Pada penelitian ini kita dapat mengetahui selama masa pertumbuhan dan perkembangan anak akan selalu membutuhkan pengenalan terhadap banyak hal yang baru salah satunya adalah pengenalan dunia luar dan berinteraksi dengan orang lain selain anggota keluarga anak perlu berinteraksi dengan orang baru tetapi dengan pegawasan orang tuanya.

\section{Simpulan}

Berdasarkan hasil penelitian ini di peroleh bahwa anak yang merupakan salah satu anak disekolah Aisyiyah Bustanul Athfal 7 yang bernama CIKA usia 5 tahun yang merupakan anak yang memiliki hambatan dalam berinteraksi sosial.

Dari observasi dan wawancara yang saya lakukan saya mendapatkan informasi bahwa ketika anak berinteraksi dengan orang yang sudah di kenalnya seperti temanteman yang ada dilingkungan sekolahnya dan lingkungan keluarganya ia terlihat begitu akrab dan aktif dalam berinteraksi tetapi saat bertemu dengan orang yang tidak di kenalnya dan orang itu berusaha untuk mengajaknya berinteraksi dia hanya diam dan tidak mau berbicara bahkan menjadi orang yang pemarah.

Karena orang tuanya tidak membiasakan ia untuk berinteraksi dengan orang lain sehingganya ia hanya terbiasa dengan orang yang sudah ia kenal. Sebagai orang tua tentu harus mengetahui bahwa rasa percaya diri merupakan sebuah pondasi penting bagi kehidupan mental dan sosial seorang anak.

Pola asuh yang keliru karena lingkungan sosial yang tidak nyaman bagi anak untuk melakukan interaksi. Tidak memberikan kesempatan untuk berinteraksi, salah satu penyebab anak pendiam dan pemalu ketika bertemu dengan orang juga karena 
tidak punya kawan sebaya sebagai teman bermain, anak tidak tahu bagaimana memperkenalkan dirinya atau berinteraksi dengan anak lain karena tidak pernah diajak bermain diluar.

Faktor yang dapat mempengaruhi perkembangan sosial anak yaitu hubungan antara orang tua, saudara. Hubungan anak dengan orang tua ataupun saudara akan terjalin rasa kasih saying, dimana anak akan lebih terbuka dalam melakukan interaksi karena terjalinnya hubungan yang baik yang di tunjang oleh komunikasi yang tepat.

\section{Daftar Pustaka}

Aisyah Siti,dkk (2014) Perkembangan Dan Konsep Dasar Pengembangan Anak Usai Dini, Tangerang Selatan: Universitas Terbuka.

Bila Salsa (2017). Inilah Tips Jitu Menghadapi Anak Yang Pemalu, Pasif Atau Sulit Bergaul. Diakses tanggal 11 April 2017 dari https://sayangianak.com/inilah-tipsjitu-menghadapi-anak-yang-pemalu-pasif-atau-sulit-bergaul/

Fridani Lara, dkk. (2011) Evaluasi Perkembangan Anak Usai Dini, Jakarta: Universitas Terbuka.

Ganil Nurmala, Wantu Tuti, Ardini Pupung Puspa. Identifikasi Kesadaran Diri pada Anak di TK Negeri Pembina Pohuwato. https://ejournalfipung.ac.id/ojs/index.php/iecej/article/view/50

Hidayati Laely (2018). Kemampuan Interaksi Social Anak Usia Dini Berdasarkan Pada Pemberian Gadget Oleh Orang Tua Di Kelurahan Sukorejo, Kecamatan Gunungpati, Kota Semaran. Universitas Negeri Semarang

Orami (2019). Cara Atasi Anak Yang Tidak Mau Berinteraksi Dengan Orang Lain. Diakses tanggal 10 juni 2019 dari https://parenting-orami-coid.cdn.ampproject.org/v/s/parenting.orami.co.id/magazine/amp/cara-atasi-anakyang-tidak-mau-berinteraksi-dengan-oranglain/?amp js $v=a 2 \& a m p$ gsa $=1 \&$ usQ $p=m Q 331$ AQCKAE\%3D\#aoh $=1576223289480$ 8\&referrer=https:\%2Fwww.google.com\&amp tf=Dari\%251\%24s\&ampshare+https :\%2F\%2Fparenting.orami.co.id\%2Fmagazine\%2Fcara-atasi-anak-yang-tidak-mauberinteraksi-dengan-orang-lain $\% 2 \mathrm{~F}$

Susanto Ahmad (2014) Perkembangan Anak Usia Dini Pengantar Dalam Berbagai Aspeknya, Jakarta: Kencana Prenamadamedia Group. 